\title{
Peningkatan Kesadaran Lingkungan dan Kesehatan Masyarakat Desa Somongari melalui Edukasi Dampak Pupuk dan Pestisida Anorganik
}

\section{(Increasing Environmental and Health Awareness of Somongari Villager Through Impact Education of Inorganic Fertilizer and Pesticides)}

\author{
Purwanti Pratiwi Purbosari1 ${ }^{*}$, Hadi Sasongko², Zuchrotus Salamah', Nurul Putrie Utami ${ }^{3}$ \\ 1 Program Studi Pendidikan Biologi, Fakultas Keguruan dan Ilmu Pendidikan, Universitas Ahmad Dahlan, \\ Jalan Ahmad Yani (Ringroad Selatan), Tamanan Banguntapan, Bantul, Yogyakarta 55166. \\ 2 Program Studi Biologi, Fakultas Matematika dan Ilmu Pengetahuan Alam, Universitas Ahmad Dahlan, Jalan Ahmad Yani \\ (Ringroad Selatan), Tamanan Banguntapan, Bantul Yogyakarta 55166. \\ 3 Program Studi Vokasi Bisnis Jasa Makanan, Universitas Ahmad Dahlan, Jalan Pramuka No. 42, Sidikan, \\ Yogyakarta 55161. \\ *Penulis Korespondensi: purwanti.purbosari@pbio.uad.ac.id \\ Diterima Agustus 2020/Disetujui Maret 2021
}

\begin{abstract}
ABSTRAK
Desa Somongari terletak di Kabupaten Purworejo, Jawa Tengah adalah desa yang terkenal sebagai penghasil buah durian dan manggis. Penghasilan masyarakatnya bergantung pada penjualan hasil kebun tersebut, namun buah manggis dan durian hanya dapat dipanen saat musim-musim tertentu, sehingga masyarakat Desa Somongari berencana membuat rumah sayur untuk memenuhi kebutuhan mereka sehari-hari. Berdasarkan data yang diperoleh melalui Forum Group Discussion (FGD) dengan perwakilan masyarakat desa dan perwakilan Kelompok Tani di desa tersebut didapatkan fakta bahwa masyarakat masih belum menggunakan pupuk dan pestisida organik. Kepraktisan serta hasil yang cepat dari pengaplikasian pupuk dan pestisida anorganik membuat masyarakat lebih banyak menggunakannya. Padahal pengaplikasian pupuk dan pestisida anorganik dapat menimbulkan dampak buruk bagi lingkungan dan kesehatan manusia. Oleh karena itu, dilakukan edukasi terhadap masyarakat Desa Somongari dengan tujuan untuk meningkatkan pengetahuan dan kesadaran masyarakat Desa Somongari terhadap kelestarian lingkungan dan kesehatan tubuh, khususnya akibat dampak pupuk dan pestisida anorganik. Metode yang dilakukan dalam pengabdian ini adalah persiapan (koordinasi dan identifikasi masalah melalui FGD), pelaksanaan (penyampaian materi), evaluasi, dan rencana tindak lanjut. Setelah kegiatan ini dilaksanakan, didapatkan hasil berupa peningkatan pengetahuan masyarakat terhadap dampak penggunaan pupuk dan pestisida anorganik. Hal ini terlihat dari nilai pre-test dan post-test yang masingmasing dilakukan sebelum dan sesudah pemaparan materi. Selain itu, keberhasilan program ini juga terlihat dari kesadaran masyarakat untuk membuat rencana tindak lanjut yang berkaitan dengan pembuatan pupuk dan pestisida organik.
\end{abstract}

Kata kunci: kesehatan, lingkungan, pestisida, pupuk, Somongari

\begin{abstract}
Somongari Village, located in Purworejo District, Central Java Province, is well-known as a producer of durian and mangosteen fruits. The income of Somongari Villagers depends on this commodity, however because of durian and mangosteen can only be harvested during a specific season, the villager plans to build vegetable houses for their daily needs. Based on the data obtained through Forum Group Discussion (FGD) with representatives of the villager and farmer group, the villager had not used organic fertilizers and pesticides. The practicality and fast yield of inorganic fertilizers and pesticides are the reasons villagers use them more. In contrast, the application of inorganic fertilizers and pesticides can hurt the environment and human health. Therefore, education was carried out for the Somongari villagers to increase the knowledge and awareness of environmental sustainability and health, primarily due to inorganic fertilizer and pesticide impact. The method used in this event was include preparation (coordination and problem identification through FGD), implementation (delivery of material), evaluation, and follow-up plans. After this activity, public knowledge of the impact of inorganic fertilizers and pesticides has increased. It can be seen from the pretest and post-test scores, respectively, before and after the material's presentation. In addition, the success of this program can also be seen from the awareness of the villager to make follow-up plans related to the production of organic fertilizers and pesticides.
\end{abstract}

Keywords: environment, fertilizer, health, pesticide, Somongari 


\section{PENDAHULUAN}

Penggunaan pupuk dan pestisida anorganik di kalangan masyarakat sudah menjadi hal yang umum. Bahkan sebagian besar petani di Indonesia sangat bergantung pada pupuk dan pestisida anorganik untuk memaksimalkan hasil pertaniannya. Pemerintah meskipun membuat berbagai macam peraturan terkait penggunaan pupuk dan pestisida anorganik, akan tetapi regulasi produksinya tidak ketat. Hal ini dapat terlihat dari data Direktorat Jenderal Prasarana dan Sarana Pertanian (Ditjen PSP Pertanian) pada tahun 2019 tercatat ada sejumlah 1.650 merek pupuk anorganik di Indonesia. Sementara itu, pestisida terdaftar sebanyak 4.447 formulasi yang terdiri dari insektisida 1.530 formulasi, herbisida 1.162 formulasi, serta 1.745 formulasi merupakan formulasi fungisida, rodentisida, pestisida rumah tangga dan lain-lain (Media Indonesia 2019).

Pupuk dan pestisida anorganik lebih diminati masyarakat dibandingkan pupuk dan pestisida organik. Hal tersebut lantaran penggunaannya yang praktis, mudah untuk didapat, harga terjangkau, serta manfaatnya yang secara cepat bisa langsung dirasakan petani. Akan tetapi, di samping kelebihannya yang banyak, penggunaan pupuk dan pestisida anorganik juga dapat memberi dampak buruk bagi lingkungan dan kesehatan manusia.

Penggunaan pupuk anorganik secara terus menerus dan tanpa disertai pengaplikasian dosis yang tepat dapat mendagradasi kesuburan tanah, bahkan merubah sifat fisik, kimia, dan biologi tanah (Maghfoer 2018). Pencemaran tanah karena pupuk dan pestisida anorganik juga dapat megakibatkan keseimbangan unsur tanah berubah (Puspawati \& Haryono 2018). Pencemaran udara dan air pun merupakan dampak yang harus diwaspadai. Makhluk hidup yang ada di sekitar lahan pengaplikasian pupuk dan pestisida anorganik dapat ikut terganggu. Di samping itu, residu dari penggunaan pupuk dan pestisida anorganik juga dapat menjadi ancaman bagi kesehatan konsumen hasil-hasil pertanian. Salah satu jenis kandungan pestisida berupa organoklorin dapat menyebabkan terganggunya keseimbangan saraf manusia hingga tremor dan kejang-kejang (Yuantari 2011).

Penelitian yang dilakukan oleh Taufik (2011) untuk melihat residu pestisida pada perairan perikanan di Sukabumi yang dekat dengan area persawahan mendapati bahwa tidak hanya air kolam budidaya ikan saja yang tercemar oleh residu pestisida, akan tetapi daging ikan yang dibudidayakan di kolam tersebut pun mengandung residu pestisida. Demikian pula pada tanah di bawah air kolam tersebut juga mengandung residu pestisida. Data menunjukkan bahwa konsentrasi residu pestisida paling besar secara berurutan ditemukan pada daging ikan, tanah, dan yang terakhir pada air kolam. Residu pestisida tersebut merupakan golongan organoklorin, organofosfat, piretroid, dan karbamat.

Sementara itu, penelitian Fatmawati \& Suparmin (2015) menemukan bahwa hasil pengujian terhadap sampel tanah di sekitar kawasan pertanian kentang Dieng ditemukan kandungan Organoklorin p;p-DDT 61,47. Padahal penggunaan pestisida organoklorin telah lama dilarang oleh pemerintah RI lantaran dampak buruk yang ditimbulkan. Organoklorin bersifat persisten dan sangat beracun, termasuk untuk organisme perairan (Wan 2013). Begitu pula yang diungkapkan oleh Puspawati \& Haryono (2018) bahwa DDT bersifat persisten atau tidak mudah diurai melalui proses kimia, fisika, dan biologi. Penelitian Fatmawati \& Suparmin (2015) tersebut juga menemukan residu organofosfat pada sampel kentang yang diteliti meskipun masih di bawah ambang batas yang ditetapkan pemerintah.

Amilia et al. (2016) mengungkapkan adanya residu pestisida pada brokoli yang ditanam di Desa Cihanjuang Rahayu, Bandung Barat. Hasil empat sampel tanaman yang diteliti, diketahui bahwa kandungan residu pestisidanya jenis klorpirifos melebihi Batas Maksimum Residu (BMR) yang ditetapkan oleh pemerintah, yaitu 10, 20, 60 dan 82\% lebih besar dari BMR. BMR yang ditetapkan oleh pemerintah tersebut mengacu pada Standar Nasional Indonesia (SNI) 7313:2008 dimana BMR khusus pada brokoli untuk jenis pestisida klorpirifos adalah $2 \mathrm{mg} / \mathrm{kg}$ (Badan Standardisasi Nasional 2008). Menurut Syahri \& Somantri (2017) melaporkan bahwa terdapat residu pestisida pada sayuran di Sumatera Selatan. Sayuran tersebut adalah cabai keriting, kentang, dan bawang merah dengan dominasi residu dari golongan organofosfat dan karbamat. Sementara itu, dari penelitian Sumiati \& Julianto (2018) diketahui adanya residu pestisida yang ditemukan pada buah jeruk di Kota Batu dan Kabupaten Malang. Buah jeruk yang mengandung residu pestisida tersebut bukan hanya buah jeruk yang baru dipanen oleh petani, tetapi juga pada buah jeruk yang sudah diperjualbelikan oleh pedagang jeruk. Residu pestisida pada buah jeruk tersebut berupa 
profenofos (golongan organofosfat) dengan kadar 0,050-0,108 ppm.

Berbagai bahan kimia termasuk pupuk atau pun residu pestisida yang masuk ke dalam tubuh manusia dapat memengaruhi kesehatan. Penelitian Amilia et al. (2016) menemukan adanya dampak langsung keracunan pestisida pada petani, yaitu mual, muntah, pusing, dan gatalgatal pada kulit. Sementara itu, Pawitra (2012) menemukan bahwa keracunan insektisida dapat berpengaruh pada penurunan aktivitas enzim kolinesterase dalam tubuh. Banyak jenis insektisida yang bekerja sebagai inhibitor bagi enzim kolinesterase di dalam tubuh serangga. Namun ternyata hal tersebut berlaku pula pada enzim kolinesterase di dalam tubuh manusia. Enzim kolinesterase adalah salah satu komponen yang dibutuhkan agar sistem saraf bekerja dengan baik pada tubuh serangga maupun manusia (Maden et al. 2015). Pestisida yang telah digunakan di lingkungan pertanian tidak akan mudah hilang. Hal ini sejalan dengan pendapat Yuantari (2011) bahwa terdapat pestisida yang sangat persisten di alam, seperti jenis DDT dan polikhlorobiphenil. Hal ini akan menambah panjang dampak yang ditimbulkan oleh pestisida, baik bagi lingkungan maupun kesehatan manusia.

Berdasarkan hasil diskusi yang dilakukan dengan metode Forum Group Discussion (FGD) dengan perwakilan masyarakat Desa Somongari dan perwakilan anggota beberapa kelompok tani di desa tersebut diketahui bahwa masyarakat selalu menggunakan pupuk dan pestisida anorganik untuk tanaman perkebunan mereka. Belum terbentuk pola kebiasaan di masyarakat Desa Somongari untuk memanfaatkan pupuk dan pestisida organik. Hal tersebut dikarenakan masyarakat merasa bahwa penggunaan pupuk dan pestisida anorganik lebih praktis, serta hasilnya bisa cepat dirasakan secara langsung. Selain itu, masyarakat juga belum mengetahui dampak negatif dari pengaplikasian pupuk dan pestisida anorganik. Padahal saat ini masyarakat Desa Somongari sedang mulai menggalakkan penanaman sayuran untuk memenuhi kebutuhan mereka sehari-hari. Oleh karena itu, perlu dilakukan edukasi kepada masyarakat secara terstruktur tentang dampak negatif penggunaan pupuk dan pestisida anorganik. Tujuan dari pengabdian ini adalah untuk meningkatkan pengetahuan masyarakat Desa Somongari tentang dampak negatif penggunaan pupuk dan pestisida anorganik. Dari hal tersebut diharapkan kesadaran masyarakat Desa Somongari untuk menjaga kelestarian lingkungan dan kesehatan diri dapat meningkat.

\section{METODE PELAKSANAAN KEGIATAN}

Kegiatan pengabdian kepada masyarakat dilakukan dari bulan Maret-Juni 2020 di Desa Somongari, Kecamatan Kaligesing, Kabupaten Purworejo, Jawa Tengah. Peserta yang terlibat adalah masyarakat Desa Somongari dan anggota kelompok tani yang ada di Desa Somongari dengan total peserta sebanyak 45 orang. Pelaksanaan pengabdian meliputi tiga tahap, yaitu tahap persiapan, pelaksanaan, evaluasi, dan rencana tindak lanjut. Metode pelaksanaan dari masing-masing tahapan berbeda satu sama lain. Hal tersebut diuraikan dalam penjelasan masingmasing tahapan.

Tahap pertama adalah tahap persiapan. Tahap ini meliputi kegiatan koordinasi dan FGD dengan perwakilan masyarakat Desa Somongari dan perwakilan kelompok tani di desa tersebut. Metode yang dilakukan pada tahapan ini adalah diskusi bersama warga. Kegiatan ini dilakukan pada tanggal 16 Maret 2020.

Tahap kedua adalah tahap pelaksanaan. Tahap ini dilakukan dengan cara penyampaian materi kepada masyarakat. Penyampaian materi ini menggunakan metode ceramah, tanya jawab, dan diskusi. Media yang digunakan adalah video, powerpoint, dan leaflet.

Tahapan yang terakhir berupa tahap evaluasi dan rencana tindak lanjut. Evaluasi dilakukan dengan metode post-test guna mengukur pengetahuan warga tentang materi yang disampaikan. Untuk mengetahui ada tidaknya peningkatan pengetahuan warga maka sebelum pemaparan materi terlebih dahulu dilakukan pre-test. Soal evaluasi terdiri dari 6 butir soal. Butir soal pertama mengevaluasi pengetahuan warga terkait manfaat pupuk, butir soal kedua terkait dampak pupuk anorganik, butir soal ketiga terkait manfaat pestisida, butir soal keempat terkait jenis pestisida berdasarkan sasaran targetnya, butir soal kelima terkait dampak pestisida anorganik, butir soal keenam terkait kelebihan pupuk dan pestisida organik.

Kegiatan terakhir adalah rencana tindak lanjut. Dalam kegiatan ini disepakati acara-acara yang akan dilakukan warga terkait dengan pembuatan pupuk dan pestisida organik. Secara keseluruhan, tahapan pelaksanaan pengabdian ini dapat dilihat pada Gambar 1. 


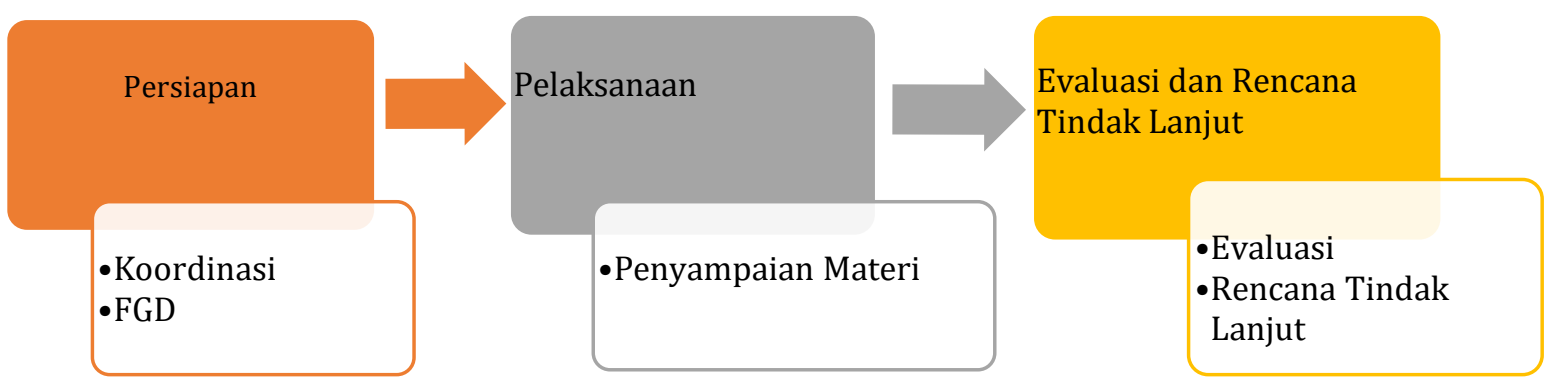

Gambar 1 Tahapan kegiatan pengabdian.

\section{HASIL DAN PEMBAHASAN}

Pupuk dan pestisida organik belum banyak dikenal oleh masyarakat. Sebaliknya, penggunaan pupuk dan pestisida anorganik sudah menjadi hal yang biasa dilakukan masyarakat, khususnya petani di Indonesia. Selain mudahnya mendapatkan dan mengaplikasikan pupuk serta pestisida anorganik, minimnya pengetahuan masyarakat tentang dampak negatif pupuk dan pestisida anorganik juga menjadi salah satu faktor penyebabnya.

Kegiatan pengabdian di Desa Somongari diawali dengan koordinasi dengan pemerintah Desa Somongari. Hal ini dilakukan setelah perizinan selesai didapatkan. Dalam koordinasi ini disepakati kegiatan yang akan dilaksanakan secara umum beserta rencana waktu kegiatannya. Selain itu, dilakukan pula Forum Group Discussion (FGD) dengan perangkat desa dan perwakilan masyarakat Desa Somongari dengan total peserta 28 orang yang dilakukan pada tanggal 16 Maret 2020. Dari kegiatan FGD ini diketahui bahwa masyarakat Desa Somongari selama ini selalu menggunakan pupuk dan pestisida anorganik untuk tanaman perkebunan mereka. Selain itu, masyarakat Desa Somongari juga belum mengetahui dampak negatif akibat penggunaan pupuk dan pestisida anorganik. Suasana saat FGD diperlihatkan dalam Gambar 2.

Pada tanggal 21 Juni 2020 selanjutnya dilakukan penyampaian materi kepada masyarakat Desa Somongari terkait dampak negatif penggunaan pupuk dan pestisida anorganik. Kegiatan ini diikuti oleh 45 warga Desa Somongari, yang terdiri dari 21 warga laki-laki dan 24 warga perempuan. Materi tentang dampak pupuk dan pestisida anorganik yang dijelaskan kepada warga mencakup dampak terhadap lingkungan, kesehatan manusia, serta dampak bagi keberlanjutan sistem pertanian itu sendiri.

Selama ini warga Desa Somongari tidak mengaplikasikan pupuk dan pestisida anorganik

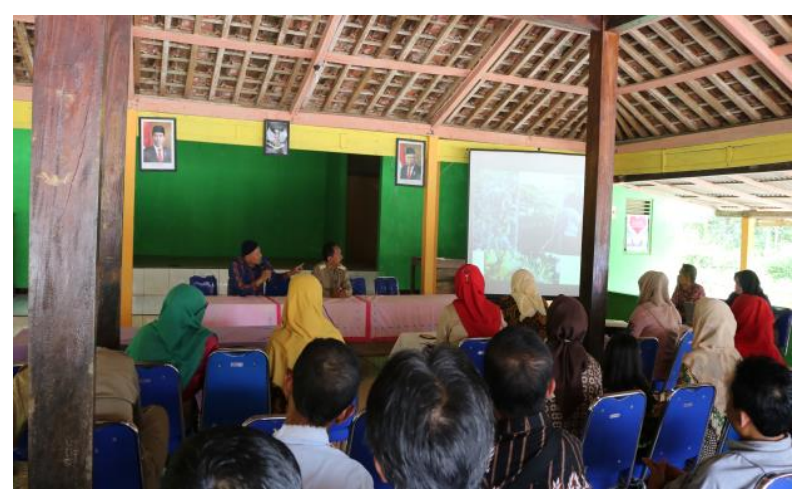

Gambar 2 Suasana Forum Group Discussion.

pada tanaman sayuran karena mereka belum pernah menanam sayuran di pekarangan rumah mereka, apalagi dalam skala besar. Akan tetapi, warga Desa Somongari mengaplikasikannya pada tanaman perkebunan mereka. Perintisan penanaman sayuran melalui pembuatan rumah sayur harus diawali dengan pemahaman yang tepat untuk mengurangi kebiasaan yang telah ada. Selain residu pupuk dan pestisida yang persisten di alam, residu yang terbawa dalam sayuran itu sendiri berpeluang lebih cepat terkonsumsi oleh manusia. Beberapa penelitian menunjukkan residu pupuk dan pestisida anorganik terkandung pada sayur mayur dan hasilhasil pertanian, contohnya pada brokoli (Amilia et al. 2016); cabai keriting dan bawang merah (Syahri \& Somantri 2017); kentang (Fatmawati \& Suparmin 2015); buah jeruk (Sumiati \& Julianto 2018).

Sementara itu, berdasarkan penelitian Fitriadi \& Putri (2016) diketahui tidak semua jenis pestisida dapat dihilangkan 100\% menggunakan pencucian dengan air mengalir. Bahkan pada residu asefat dan thiram penurunan kadarnya masih kurang dari 50\% setelah pencucian menggunakan air biasa. Hal ini dikarenakan jenis residu tersebut merupakan jenis yang tidak mudah larut dalam air. Sementara itu, metode pencucian sayur dan buah yang biasa dilakukan oleh masyarakat saat akan mengkonsumsi sayur 
dan buah adalah dengan pencucian menggunakan air biasa.

Saat awal penyampaian materi, dibagikan angket untuk melihat persepsi masyarakat tentang sayur-sayuran yang biasa dibeli dari penjual sayur atau pasar. Masing-masing peserta diberi pertanyaan apakah mereka yakin bahwa sayuran yang diperjualbelikan benar-benar terbebas dari pupuk dan pestisida anorganik. Data tersebut ditampilkan pada Gambar 3. Berdasarkan angket ini diketahui bahwa sebagian besar masyarakat menganggap bahwa sayur-sayuran yang dibeli dari pasar atau pedagang sayur tidak terbebas dari pupuk dan pestisida anorganik. Hal ini seharusnya menjadi motivasi tersendiri untuk meminimalisasi konsumsi sayuran yang biasa diperjualbelikan dan dapat mendorong untuk giat menanam sayuran di rumah sendiri. Kesadaran tersebut akan semakin tumbuh jika masyarakat juga diberi edukasi tentang dampak pupuk dan pestisida anorganik.

Penyampaian materi dilakukan dengan metode dan media yang beragam. Metode yang digunakan adalah ceramah, tanya jawab, dan diskusi. Sementara itu, media yang digunakan meliputi video, leaflet, dan powerpoint. Hal ini bertujuan untuk mendukung dan meningkatkan penyerapan materi oleh masyarakat. Penggunaan media audiovisual dalam penyuluhan berdasarkan penelitian Marizi et al. (2019) efektif meningatkan pengetahuan masyarakat. Sebesar $70 \%$ masyarakat peserta penyuluhan meningkat pengetahuannya menjadi kategori baik dibandingkan sebelum penyuluhan, yaitu sebesar 13,3\%. Sementara itu, hasil penelitian Hamtiah, dkk (2012) menunjukkan bahwa terjadi peningkatan pengetahuan masyarakat peternak di Desa Indrokilo setelah dilakukan penyuluhan menggunakan media audiovisual dengan persentase perubahan peningkatan pengetahuan sebesar $15,3 \%$. Suasana saat penyampaian materi dapat dilihat pada Gambar 4.

Setelah penyampaian materi, tahapan selanjutnya yaitu evaluasi dan rencana tindak lanjut. Evaluasi dilakukan untuk mengukur tingkat penyerapan materi oleh peserta. Teknik evaluasi yang diterapkan adalah dengan cara pemberian soal post-test kepada peserta. Hasil post test yang didapat selanjutnya dibandingkan dengan hasil pre-test yang diambil sebelum penyampaian materi. Dari tahap evaluasi ini diketahui bahwa terjadi peningkatan pengetahuan masyarakat Desa Somongari terkait dengan dampak negatif penggunaan pupuk dan pestisida anorganik.

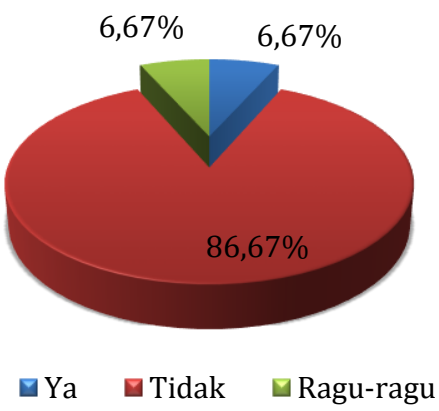

Gambar 3 Persepsi masyarakat Desa Somongari terhadap sayur-sayuran yang diperjualbelikan.

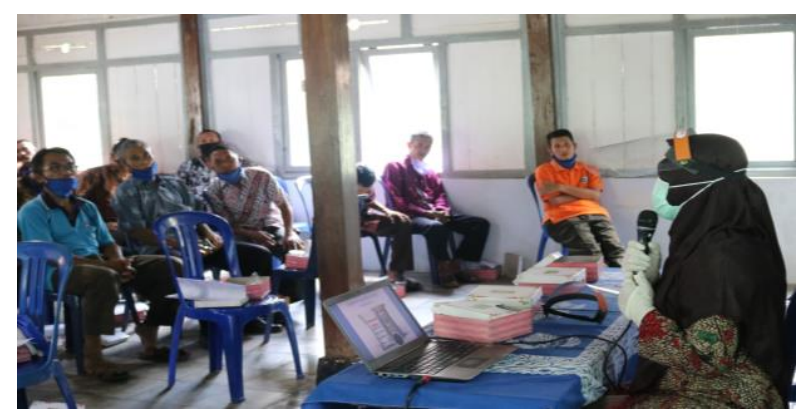

Gambar 4 Suasana penyampaian materi.

Secara terperinci peningkatan tersebut dapat dilihat dalam Gambar 5.

Berdasarkan Gambar 5 dapat kita ketahui bahwa pada butir evaluasi 1 , terjadi peningkatan pengetahuan masyarakat Desa Somongari terkait dampak negatif penggunaan pupuk dan pestisida anorganik sebesar $2,2 \%$, pada butir evaluasi 2 sebesar $31,1 \%$, pada butir evaluasi 3 sebesar $15,5 \%$, pada butir evaluasi 4 sebesar $22,2 \%$, pada butir evaluasi 5 sebesar 35,5\%, dan pada butir evaluasi 6 sebesar 40\%. Dari seluruh butir evaluasi tersebut dapat diketahui bahwa terjadi peningkatan pengetahuan masyarakat Desa Somongari setelah mengikuti kegiatan edukasi terkait dampak negatif penggunaan pupuk dan pestisida anorganik terhadap lingkungan dan kesehatan.

Selain terjadinya peningkatan pengetahuan masyarakat Desa Somongari, indikator keberhasilan lainnya dari kegiatan pengabdian ini dapat dilihat dari antusiasme warga saat mengikuti kegiatan dan kesadaran masyarakat untuk membuat rencana tindak lanjut dari kegiatan ini. Rencana tindak lanjut ini meliputi serangkaian rencana pelatihan pertanian organik, di antaranya pelatihan pembuatan berbagai jenis pupuk organik dan pelatihan pembuatan berbagai jenis pestisida organik sehingga masyarakat dapat benar-benar membuat pupuk 


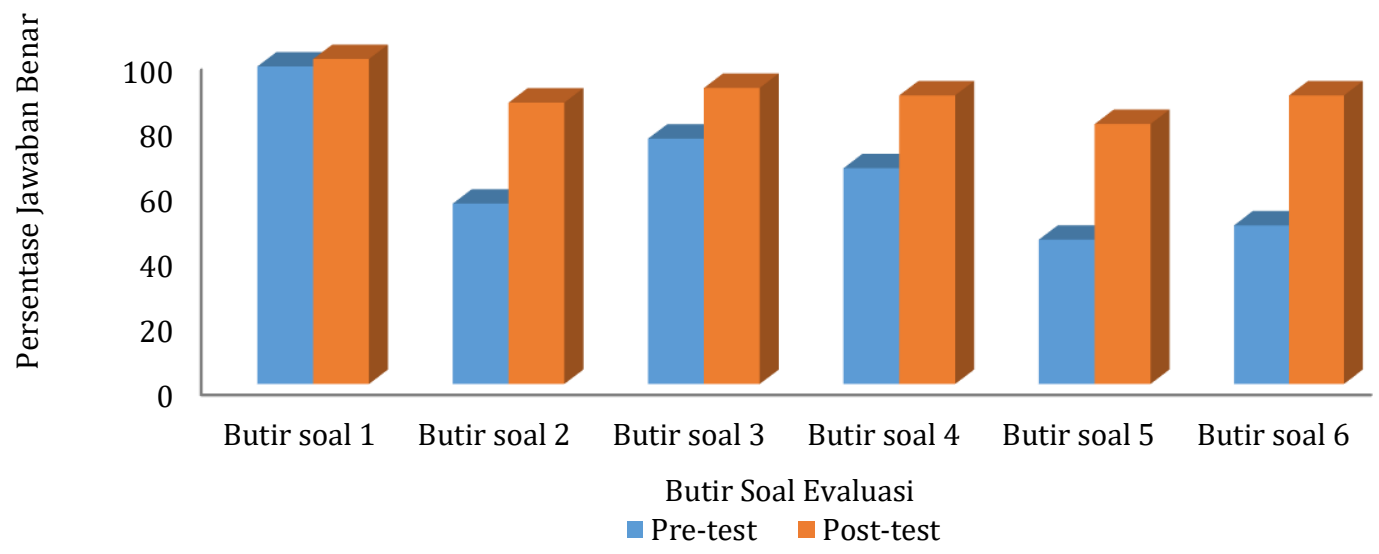

Gambar 5 Peningkatan persentase jawaban benar peserta kegiatan edukasi (45 warga).

dan pestisida organik untuk tanaman sayur yang mereka tanam. Rencana tindak lanjut ini dibuat dalam kelompok-kelompok berdasarkan daerah asal dari peserta pelatihan. Total sebanyak 32 kelompok yang membuat rencana tindak lanjut yang mewakili jumlah kelompok rumah sayur di Desa Somongari. Akan tetapi dalam pelaksanaannya hanya 30 kelompok rumah sayur yang kegiatannya berjalan dengan baik untuk memproduksi berbagai jenis pestisida dan pupuk organik.

\section{SIMPULAN}

Kegiatan pengabdian di Desa Somongari Kabupaten Purworejo meliputi tiga tahapan kegiatan, yaitu tahap persiapan, tahap pelaksanaan, serta tahap evaluasi dan rencana tindak lanjut. Tahap persiapan meliputi koordinasi dan FGD dengan perwakilan masyarakat Desa Somongari dan perwakilan kelompok tani. Tahap pelaksanaan, dilakukan dengan cara penyampaian materi kepada masyarakat. Selanjutnya, tahapan yang terakhir berupa evaluasi dan rencana tindak lanjut. Berdasarkan hasil evaluasi tersebut diketahui terjadi peningkatan pengetahuan warga terkait dengan dampak penggunaan pupuk dan pestisida anorganik terhadap lingkungan dan kesehatan. Selain itu juga terdapat kesadaran masyarakat untuk membuat rencana tindak lanjut terkait pembuatan pupuk dan pestisida organik.

\section{UCAPAN TERIMA KASIH}

Ucapan terima kasih diberikan kepada Kementerian Riset dan Teknologi/Badan Riset dan Inovasi Nasional serta Universitas Ahmad
Dahlan yang telah membiayai kegiatan pengabdian ini dalam skema Program Pengembangan Desa Mitra (PPDM) dengan nomor kontrak L1/001/C.6/III/2020.

\section{DAFTAR PUSTAKA}

Amilia E, Joy B, Sunardi. 2016. Residu Pestisida pada Tanaman Hortikultura (Studi Kasus di Desa Cihanjuang Rahayu Kecamatan Parongpong Kabupaten Bandung Barat). Jurnal Agrikultura. 27(1): 23-29. https://doi. org/10.24198/agrikultura.v27i1.8473

[BSN] Badan Standardisasi Nasional. 2008. SNI 7313:2008 Batas Maksimum Residu Pestisida pada Pertanian.

Fatmawati, Suparmin. 2015. Studi Pemakaian Pestisida pada Petani Kentang di Desa Dieng Kecamatan Kejajar Kabupaten Wonosobo Tahun 2015. Buletin Keslingmas. 34(4): 242249. keslingmas.v34i4.3038

https://doi.org/10.31983/

Fitriadi BR, Putri AC. 2016. Metode-metode Pengurangan Residu Pestisida pada Hasil Pertanian. Jurnal Rekayasa Kimia dan Lingkungan. 11(2): 61-71. https://doi.org/ 10.23955/rkl.v11i2.4950

Hamtiah S, Dwijatmiko S, Satmoko S. 2012. Efektivitas Media Audio Visual (Video) terhadap Tingkat Pengetahuan Petani Ternak Sapi Perah Tentang Kualitas Susu di Desa Indrokilo Kecamatan Ungaran Barat Kabupaten Semarang. Animal Agriculture Journal. 1(2): 322-330.

Maden EVD, Gordijn F, Wulansari M, Koomen I. 2015. Panduan Pelatihan Paparan Pestisida di 
Ladang dan Pengaruh pestisida terhadap Kesehatan. Veg Impact, Netherland (NL): Wageningen UR.

Maghfoer MD. 2018. Teknik Pemupukan Terung Ramah Lingkungan. Malang (ID): Universitas Brawijaya Press.

Marizi L, Novita N, Setiawati D. 2019. Efektivitas Media Audiovisual tentang Kontrasepsi Intra Uterine Device terhadap Pengetahuan Wanita Usia Subur. Jurnal Kesehatan Poltekkes Palembang. 14(1): 7-12. https://doi.org/ 10.36086/jpp.v14i1.280

Media Indonesia. 2019. Pemerintah Tertibkan Peredaran Pupuk dan Pestisida. [Internet] [Diakses pada: 28 Mei 2020]. Tersedia pada: https://mediaindonesia.com/ekonomi/2383 $15 /$ pemerintah-tertibkan-peredaran-pupukdan-pestisida.

Pawitra AS. 2012. Pemakaian Pestisida Kimia terhadap Kadar Enzim Cholinesterase dan Residu Pestisida Dalam Tanah. Jurnal Ilmiah Kesehatan Media Husada. 01(01): 19-30. https://doi.org/10.33475/jikmh.v1i1.59

Puspawati C, Haryono P. 2018. Bahan Ajar Kesehatan Lingkungan Penyehatan Tanah. Jakarta (ID): Pusat Pendidikan Sumber Daya Manusia Kesehatan Edisi Tahun 2018, Kementerian Kesehatan Republik Indonesia.
Sumiati A, Julianto RPD. 2018. Analisa Residu Pestisida di Wilayah Malang dan Penanggulanganya untuk Keamanan Pangan Buah Jeruk. Buana Sains. 18(2): 125-130. https://doi.org/10.33366/bs.v18i2.1185

Syahri, Somantri RU. 2017. Studi Dampak Aplikasi Pestisida terhadap Residu yang Ditimbulkannya pada Sayuran di Sumatera Selatan. Dalam: Prosiding Seminar Nasional Lahan Suboptimal 2017. Palembang (ID): Universitas Sriwijaya, 19-20 Oktober 2017.

Taufik I. 2011. Pencemaran Pestisida pada Perairan Perikanan di Sukabumi-Jawa Barat. Media Akuakultur. 6(1): 69-75. https://doi. org/10.15578/ma.6.1.2011.69-75

Yuantari MG. 2011. Dampak Pestisida Organoklorin terhadap Kesehatan Manusia dan Lingkungan serta Penanggulangannya. Dalam Prosiding Seminar Nasional Peran Kesehatan Masyarakat dalam Pencapaian $M D G$ 's di Indonesia. Jakarta (ID): Universitas Muhammadiyah Prof. Dr. HAMKA, 12 April 2011.

Wan MT. 2013. Ecological Risk of Pesticide Residues in The British Columbia Environment. Journal of Enfironmental Science and Health. 48(5): 344-363. https:// doi.org/10.1080/03601234.2013.742373 